\title{
Technical and Financial Feasability Analysis of Mangrove (Bruguiera gymnorrhiza) Starch Production in West Seram District, Maluku Province
}

\author{
Melkhianus \\ Doctoral Program of Fisheries and Marine Sciences, Brawijaya University \\ H. Pentury \\ Fisheries Processing Department, Fisheries Academy, Biak \\ Happy Nursyam \\ Processing Department, Faculty of Fisheries and Marine Science, Brawijaya University \\ Nuddin Harahap \\ Fisheries and Marine Socio-Economics Department \\ Faculty of Fisheries and Marine Science, Brawijaya University \\ Soemarno
}

Soil Science Department, Faculty of Agriculture, Brawijaya University

Received: Oct. 6, 2013 Accepted: November 18, 2013 Published: December 1, 2013

doi:10.5296/jfs.v2i2.4978ＵRL: http://dx.doi.org/10.5296/jfs.v2i2.4978

\begin{abstract}
The hypocotyls of Bruguiera gymnorrhiza have a high carbohydrate content, but have not been widely used as a staple food. An alternative use for Bruguiera gymnorrhiza hypocotyls is for the manufacture of starch. In addition to seeking new sources of starch for modern food industry. The research method used a completely randomized factorial design with three replicates and 2 treatment factors: $\mathrm{NaHSO}_{3}$ concentrations of $0.10 \% .0 .20 \% .0 .25 \%$ and $0.40 \%$ and temperatures of $40^{\circ} \mathrm{C}, 50^{\circ} \mathrm{C}$ and $60^{\circ} \mathrm{C}$. Data analysis was carried out using SPSS version 16.0. The best treatment was determined using the De Garmo method. The results show that the best results were obtained from the treatment with a heating time of 5 minutes at $60{ }^{\circ} \mathrm{C}$ with $0.40 \% \mathrm{NaHSO}$ concentration, producing $21.35 \%$ amylose content, $64.30 \%$ starch content, a viscosity of $40.33 \%$, $89.99 \%$ solubility and $0.16 \%$ monosaccharide content. a required investment of IRD. 88,550,000. The Net Present Value (NPV) analysis returned a
\end{abstract}




\section{Macrothink}

Journal of Food Studies ISSN 2166-1073 2013, Vol. 2, No. 2

figure of 90,011,325. The Internal Rate of Return (IRR) analysis gave a value of $46.81 \%$. The Payback Period (PP) analysis shows that the initial investment could be recouped within a period of 4 years and 3 months. The $\mathrm{B} / \mathrm{C}$ ratio was 1.1. Based on the investment criteria analysis, it would be viable to establish this industry in West Seram District.

Keywords: Bruguiera gymnorrhiza, Extraction, Starch, Feasibility analysis 


\section{Introduction}

The use of Bruguiera gymnorrhiza hypocotyls in food processing has so far been limited to the use of flour produced naturally with no modern processing. An appropriate processing method is required to increase the economic value of Bruguiera gymnorrhiza hypocotyls (Wanma, 2007). Bruguiera gymnorrhiza hypocotyls have a high carbohydrate content (Fortuna, 2005; Sadana, 2007; Purnobasuky, 2012) and a fairly high starch content (Pentury, 2010). Starch is the most important nutrient in everyday diet, and the ever-growing need for starch in the modern global food industry has driven efforts to identify new sources of polysaccharide starch (Ancona et al, 2001). The highest starch content is found in green and unripe fruits, and can be as high as $70 \%$ of dry weight. Based on the above facts, Bruguiera gymnorrhiza hypocotyls could become an alternative source of starch, alongside grains (maize, wheat and rice).

Bruguiera gymnorrhiza hypocotyls can be readily found in almost all areas of Indonesia. However their use has been limited to ecological functions. Of course Bruguiera gymnorrhiza hypocotyls do not keep for long, and need to be converted into a versatile product with long shelf life and high nutritional content. In this context, there is a need to develop Bruguiera gymnorrhiza hypocotyl starch production methods and to study the nutritional value and functionality of this product as well as the amylose content, solubility, monosaccharide content and viscosity to provide guidelines for its use in food products. In addition, the Bruguiera gymnorrhiza starch produced should increase the shelf-life of this starch source and prevent decay.

The expected benefits from this research include the determination of the correct concentration and processing heat in order to optimize the quality of the Bruguiera gymnorrhiza hypocotyl starch produced, and the development of opportunities to use hypocotyl starch from Bruguiera gymnorrhiza as a raw ingredient in the food industry. The goal of this research was to evaluate the technical and financial viability of Bruguiera gymnorrhiza hypocotyl starch production.

\section{Research and Method}

This research was undertaken in the Fisheries Processing Laboratory of the Faculty of Fisheries and Marine Science of Brawijaya University in Malang, Indonesia. The methods used were both descriptive and experimental.

\subsection{Experimental Data Collection}

Bruguiera gymnorrhiza hypocotyls were peeled, cleaned and cut into pieces $<0.5 \mathrm{~cm}$ the soaked for 48 hours to reduce the tannin content before extraction. A completely randomized factorial design was used with three replicates and 2 treatment factors: the heating temperature with values of $40^{\circ} \mathrm{C}(\mathrm{S} 1), 50^{\circ} \mathrm{C}(\mathrm{S} 2)$ and $60^{\circ} \mathrm{C}(\mathrm{S} 3)$; and the concentration of the $\mathrm{NaHSO}_{3}$ solution with values of $0.10 \%(\mathrm{KA}), 0.20 \%$ (KB), 0.25 (KC), $0.40 \%$ (KD). All treatments were applied for 5 minutes. 


\subsection{Data Analysis}

The experimental data were analysed using SPSS version 16.0 software. A Duncan test was then applied to evaluate the differences between means for the various treatments. The parameters tested were starch content, amylose content, solubility, monosaccharide content and viscosity. The best treatment was selected using a weighted effectiveness index (De Garmo et al., 1984). The results were used as the basis for a technical and financial analysis of small-scale industrial starch production.

\section{Results and Discussion}

\subsection{Characterisation of Bruguiera gymnorrhiza starch}

The calculations show that the best combination of the various research parameters was obtained from the treatment using an $0.25 \% \mathrm{NaHSO}_{3}$ solution concentration combined with a heating temperature of $60^{\circ} \mathrm{C}\left(\mathrm{S}_{3} \mathrm{KC}\right)$. This most effective treatment produced an amylose content of $19.58 \%$, a starch content of $65.61 \%$, a viscosity value of $733.66 \mathrm{cP}$, a monosaccharide content of $3.07 \%$ and a solubility of $91.99 \%$; yield was $15.74 \%$ and degree of whiteness was $46.62 \%$, with an overall result of (Nh) 0.681 .

The results showed that initially increasing the concentration of natrium bisulphite increased the amylose and starch contents, however the starch content reached an optimum at a concentration of $0.25 \%$ and was reduced at $0.40 \%$. This is similar to Efendi., (2011) who stated that the concentration of sodium bisulphite increased the Yield, fat and free fatty acids. The reduction in the percentage of starch was also caused by an increase in the concentration of sodium bisulphite. The more sodium bisulphite is used, the greater the amount of starch which is oxidised and dissolved in the oxidising solution.

\subsection{Analysis of Marketing Aspects}

The potential market for Bruguiera gymnorrhiza starch in Indonesia would be similar to that of starch from cereal flour and similar products. Based on data from the Ministry for Industry, national consumption of flour is continuously increasing. By the first semester of 2013, consumption had reached 2.6 million metric tons, an increase of 1.08 percent compared to the same period in 2012. Domestic flour production had a 90\% market share in supplying raw materials to the national food industry, the remainder being imported. National flour production in 2010 was 3.6 million metric tons, rising to 4 million tons in 2011 and 4.6 million tons in 2012. The average monthly demand was around 400,000-450,000 metric tons/month. These data show that there is an opportunity for Bruguiera gymnorrhiza hypocotyl starch to compete in the domestic market. 
Table 1. Indonesian Imports of Various Starches

\begin{tabular}{|l|r|r|r|}
\hline \multirow{2}{*}{\multicolumn{1}{|c|}{ Starch type }} & \multicolumn{3}{|c|}{$\begin{array}{c}\text { Starch Import Volume } \\
\text { (Metric Tons/Year) }\end{array}$} \\
\cline { 2 - 4 } & 2009 & 2010 & \multicolumn{1}{c|}{2011} \\
\hline Wheat starch & 1,198 & 3,010 & 1,241 \\
\hline Maize (corn) starch & 79,730 & 253336 & 96,757 \\
\hline Potato starch & 14,071 & 14,296 & 8,873 \\
\hline Cassava starch & 166,813 & 294,832 & 435,419 \\
\hline Sago starch & 3,401 & 0 & 500 \\
\hline Other starches & 25 & 7,366 & 10,156 \\
\hline Inulin & 2,569 & 4,022 & 3,744 \\
\hline
\end{tabular}

Source: Kemenperin, 2011

\subsubsection{Raw Materials Analysis}

The mangrove forests in Maluku Province cover 165,775 ha (Bapedalda Provinsi Maluku, 2004). More specifically, data from a LandSat 7 ETM+ image in 2005 showed that mangrove forests in West Seram District cover 3,823.30 ha, with 553.84 ha in Kotania Bay, and Bruguiera gymnorrhiza is the most dominant species. An estimate of the production area was made through dividing the total mangrove area by the number of species present (17) resulting in a conservative figure of 32.6 ha. As the mangrove distribution is uneven and parts of the coast are difficult to access, $60 \%$ of this area was taken and rounded to the nearest integer to produce a production area estimate of 20 ha.

\section{a. Raw Material Specifications}

The main raw material used to produce Bruguiera gymnorrhiza starch is the hypocotyls of the Bruguiera gymnorrhiza growing in the production region. The hypocotyls are harvested when still immature or unripe and green in colour, because such unripe hypocotyls contain more starch than mature ripe hypocotyls in which much of the starch has been converted to sugar. Ripe hypocotyls are dark and puIRDlish in colour. Starch was extracted from the hypocotyls using the optimised process, so that the flour produced had the most favourable composition, containing 19.58\% amylose, 65.61\% starch, 3.07\% monosaccharide with 733.66 cP viscosity $91.99 \%$ solubility, $15.74 \%$ yield and $46.62 \%$ whiteness.

\section{b. Raw Material Availability}

The distance between naturally occurring Bruguiera gymnorrhiza was around 5x5 metres, giving a density of around 400 trees/ha. Each tree can produce around 200 hypocotyls per harvest; as there are around 25 fruit per $1 \mathrm{~kg}$, each tree can produce around $8 \mathrm{~kg}$ and 1 hectare of mangrove forest (Bruguiera gymnorrhiza) can produce around 3,200 kg. With a processing yield of around $15.74 \%$, and around 3,200 kg of fruit produced per ha, around $500 \mathrm{~kg} / \mathrm{ha}$ of starch could be produced, giving a production volume of $10,000 \mathrm{~kg}$ of starch per harvesting season from an area of 20 ha. This production capacity could potentially be increased as not all of the mangrove forest is considers to be a production area. 


\section{Macrothink}

Journal of Food Studies

ISSN 2166-1073

2013, Vol. 2, No. 2

\subsubsection{Planning Production Capacity}

Based on a raw material availability of $500 \mathrm{~kg}$ of Bruguiera gymnorrhiza starch per harvest and considering the market demand of 400,000-450,000 metric tons/month, as well as the still relatively large need for imports, and the extent and productivity of hypocotyl-producing Bruguiera gymnorrhiza stands in West Seram District, production capacity was set at 100 $\mathrm{kg} /$ day. This means that with an area of 20 ha, around 400 trees per hectare and around 200 hypocotyls per harvest per tree weighing in at an average of 25 hypocotyls/kg, each tree should produce on average around $8 \mathrm{~kg}$ of hypocotyls.

\subsubsection{Production Technology and Process}

Small-scale industrial production of Bruguiera gymnorrhiza starch requires simple and relatively inexpensive equipment. The Bruguiera gymnorrhiza starch production process is shown in Figure 1.

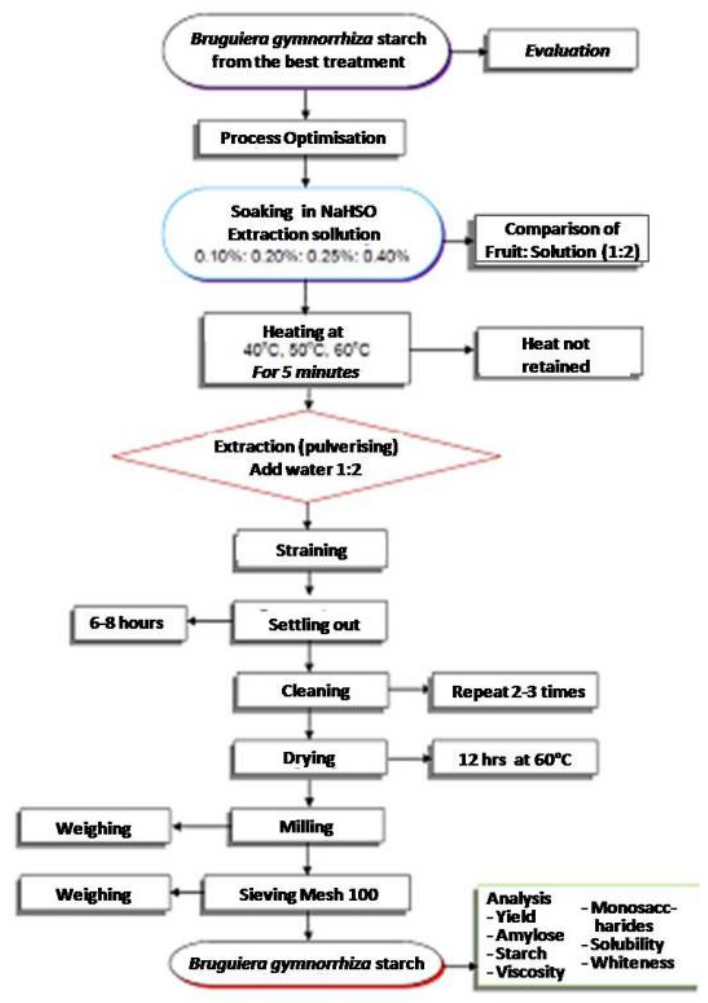

Figure 3.3. Bruguiera gymnorrhiza starch production process

\subsection{Financial Analysis}

\subsubsection{Investment}

Investment costs comprise fixed assets and include the costs of renting premises, purchasing machinery and equipment, a number of fixed assets, initial activities or pre-investment costs, contingency funds, and the provision of various other support facilities. In this study we 
calculated the total investment costs for setting up a Bruguiera gymnorrhiza starch factory with a production capacity of $100 \mathrm{~kg}$ per day to be IRD. 88,550,000.

Table 2. Investment Costs for Setting up a Bruguiera gymnorrhiza starch factory

\begin{tabular}{|ll|r|}
\hline No & \multicolumn{1}{|c|}{ Cost Component } & Outlay (IRD.) \\
\hline 1 & Pre-investment & $4,000,000$ \\
2 & Hire of Premises & $12,000,000$ \\
3 & Machinery \& Equipment & $46,000,000$ \\
4 & Support Facilities & $20,750,000$ \\
5 & $10 \%$ Contingency Fund & $5,800,000$ \\
\hline & Total & $\mathbf{8 8 , 5 5 0 , 0 0 0}$ \\
\hline
\end{tabular}

\subsubsection{Production Costs}

Production costs are outgoings made by the company in order to obtain raw materials and pay for production factors in order to produce a product. The production cost components are: raw materials, packaging materials, supporting facilities, wages and labour costs, administrative and marketing/sales costs. Te total costs incurred in producing Bruguiera gymnorrhiza starch are shown in Table 3.2. The total annual production costs for the Bruguiera gymnorrhiza starch product was calculated as IRD. 127,072,600.

Table 3. Annual (1 year) Production Cost Components for Bruguiera gymnorrhiza Starch

\begin{tabular}{|l|l|r|}
\hline No & \multicolumn{1}{|c|}{ Component } & \multicolumn{1}{|c|}{ Cost (IRD) } \\
\hline 1 & Raw materials & $81,405,000$ \\
2 & Packaging materials & 594,000 \\
3 & Supporting facilities & $1,809,600$ \\
4 & Wages and labour & $30,720,000$ \\
5 & Administrative overheads & $3,360,000$ \\
6 & Marketing/Sales costs & $3,384,000$ \\
7 & Maintenance and Repairs & $5,800,000$ \\
\hline
\end{tabular}

\subsubsection{Basic Production Costs}

Bruguiera gymnorrhiza starch was packed in $1 \mathrm{~kg}$ plastic bags. The annual production capacity of Bruguiera gymnorrhiza starch was 270 metric tons. The basic or net production cost (HPP) of each kg of Bruguiera gymnorrhiza starch was calculated to be IRD. 4,000. Based on this 
figure the suggested retail price was IRD 6,500, with a 25\% mark-up. This calculation was made because the current market price of starch as a raw material or ingredient varied from IRD. $5,000 / \mathrm{kg}$ to IRD. 7,500/kg. Annual production costs were calculated, including all fixed and variable costs for 1 year comprising raw materials, labour and other costs.

\subsubsection{Income Analysis}

Gross income was calculated by multiplying the product volume by the unit price. At the beginning of a project the production facilities are generally not being pressed to produce maximum output, and production tends to rise gradually so that income will also grow steadily year by year. In this project it was planned to sell the Bruguiera gymnorrhiza starch product with a price of IRD. 6,500/kg, which was assumed to remain constant during the project life with a maximum annual production capacity of $27,000 \mathrm{~kg}$. It was therefore estimated that the annual gross company income would be IRD. 175,500,000 if the factory operated at full capacity.

\subsubsection{R/C Ratio}

Total income from the Bruguiera gymnorrhiza starch production plant of IRD. 175,500,000and total costs of IRD. $137,077,600$ produce an $\mathrm{R} / \mathrm{C}$ ratio of 1.28 . This figure is greater than so that the Bruguiera gymnorrhiza starch production business should be profitable. The $\mathrm{R} / \mathrm{C}$ ratio of 1.28 means that the capital invested will produce revenue 1.28 times greater than the expenditure incurred.

\subsubsection{Profitability}

Profit is the result of subtracting all costs incurred by the company from the total revenue. With a total annual revenue of IRD. 175,500,000 and total production costs of IRD. 137,077,600, subtracting total costs from total revenue yields an average annual profit of IRD. 38,422,400.

\subsubsection{Rentability}

The rentability of a business is the ratio of between operational profit and the capital used to produce this profit, including both internal and outside investment, expressed as a percentage. With a rentability of $49.1 \%$, the Bruguiera gymnorrhiza starch production business could produce an operational profit of $49.1 \%$ for the capital used over a period of one year. Because Rentability is often used to evaluate the efficiency of the use of capital within a company, economic rentability is also often considered to represent the ability of a company to make use of all the capital working within it to make a profit.

\subsubsection{Break Event Point (BEP)}

The Break Event Point (BEP) is the point at which the production volume produces neither profit nor loss. "The result obtained on the basis of sale value was IRD.193,885 kg. per day". And the BEP for the production unit was $30 \mathrm{~kg} /$ day. This means that the Bruguiera gymnorrhiza starch plant would neither make a profit nor make a loss if a minimum production volume of $30 \mathrm{~kg} / \mathrm{day}$ could be maintained. This figure indicates the break-even point for sales at which sales of Bruguiera gymnorrhiza would yield neither profit nor loss. 


\subsection{Feasibility Analysis}

\subsubsection{NPV (Net Present Value)}

In a Net Present Value analysis, all future cash flow expenditures and receipts are converted to Present Value and added up to produce an accumulated value of all cash flow during the life of the investment. This calculation produced an NPV value of 90,011,325 assuming a ten year project life. This figure represents the net benefit which will accrue during the next ten years based on current value. The NPV is greater than zero which means that the project is viable.

\subsubsection{Internal Rate of Return (IRR)}

The Internal Rate of Return represents the flow of returns on investment which will produce a condition where NPV of incoming cash flow $=$ NPV or outgoing cash flow. A project is feasible to implement if the IRR value is greater than the desired minimum rate of return which is usually based on bank interest rates. The IRR of this project was calculated as $46,81 \%$. This value indicates that the project would be viable because the IRR is higher than current bank interest rates which are around $19 \%$.

\subsubsection{Net Benefit Cost Ratio (Net B/C)}

This criterion compares the benefits from the project with the costs of implementing the project. The calculations produced a Net B/C value of 1.1. This value is greater than 1 , meaning that implementing the project would be financially viable.

\subsubsection{Payback Period}

Calculating the Payback Period is one way to work out the time it would take to repay the initial investment, and is given in years. The payback period for this business venture was calculated as 4 years and 3 months. This period is shorter than the projected project life of 10 years, so that it can be considered worthwhile to pursue the Bruguiera gymnorrhiza starch production scheme.

\subsubsection{Sensitivity analysis}

Sensitivity analyses were applied to two parameters, firstly increases in the cost of raw materials and secondly a fall in retail price. This analysis will show whether or not the business will be sensitive to decisions taken with respect to certain changes. The results of the sensitivity analysis are shown in Table 4.

Table 4. Sensitivity Analysis for increases in raw material costs and reduction in retail price.

\begin{tabular}{|l|c|c|c|}
\hline \multirow{2}{*}{ Change } & \multicolumn{3}{|c|}{ Investment Criteria } \\
\cline { 2 - 4 } & NPV (IRD) & IRR (\%) & Net B/C \\
\hline Raw material costs increase by 5\% & $87,051,478$ & 43.83 & 1.0 \\
Retail price decrease of 5\% & $80,357,673$ & 40.80 & 1.0 \\
\hline
\end{tabular}


Based on the calculations shown above, in normal conditions the production of Bruguiera gymnorrhiza starch would be feasible because the business meets investment viability criteria. Should there be an increase of $5 \%$ in raw material costs, Bruguiera gymnorrhiza starch production would still be viable even though there would be a reduction in net benefits. Similarly, a reduction in retail price would also reduce benefits. However the Net B/C ratio is at the break even point so that any increase of more than $5 \%$ in raw material costs or decrease of more than 5\% in retail price would cause the business to run at a loss or fail. In general it can be concluded that the production of Bruguiera gymnorrhiza starch would be sensitive to raw material costs and retail prices.

\subsection{Socio-economic Impact Analysis}

Establishing a new industry in a given area will have direct and indirect impacts on the lives of people nearby and the surrounding environment. In the case of the proposed project to establish a Bruguiera gymnorrhiza starch production industry in West Seram District, the main impact felt by surrounding communities would be the opening up of new opportunities for employment. The wages or other remuneration of employees and casual workers in the Bruguiera gymnorrhiza starch business would have a direct impact on the economic condition in the surrounding area and would also increase the consumption of the goods and services on offer, thus having an indirect effect on the local economy.

Another effect of establishing starch production from Bruguiera gymnorrhiza hypocotyls in West Seram District would be the utilization of the Bruguiera gymnorrhiza mangrove stands. These stands which have been unexploited up to now could then used to provide economic benefits. The advent of the Bruguiera gymnorrhiza starch industry would mean increasing use of Bruguiera gymnorrhiza hypocotyls and would therefore increase community awareness and communities living around the mangrove ecosystem should become more careful not to exploit the mangroves indiscriminately and even begin to care for and maintain their mangroves to ensure a continuous supply of "raw materials for starch production"

The business plan for this industry includes working with local communities to obtain the Bruguiera gymnorrhiza hypocotyls as the raw material for starch production, so that the Bruguiera gymnorrhiza hypocotyls which had been valueless would provide economic benefits for local people.

\section{Conclusion}

The technical feasibility analysis shows that West Seram District has potential for the development of a Bruguiera gymnorrhiza starch industry because raw materials are abundant there. The market opportunities for Bruguiera gymnorrhiza starch are quite good, because a large proportion of starch needs are still provided through imports. West Seram District has more extensive mangrove forests than the other districts in Maluku Province which have mangrove ecosystems, and also has the status of a "Kawasan Ekonomi Khusus" (Special Economic Zone) with access to industries which require starch as a raw material. 


\section{Macrothink

The financial viability analysis produced an NPV of 90,011,325, a Net B/C of 1.1 and an IRR of $4.81 \%$. Therefore it can be concluded that it would be financially viable to establish an industrial plant to produce Bruguiera gymnorrhiza starch in West Seram District.

\section{References}

Alfredo Wanma. (2007). Pemanfaatan Hutan Mangrove, Bruguiera gymnorhiza (L) Lamk Sebagai Bahan Penghasil Carbohydrate, Buletin Konservasi Lahan Basa

Bapedalda Provinsi Maluku, 2004. Luas Hutan Mangrove di West Seram District.

Betancur-Ancona, D. A., Chel-Guerrero, L. A., Camelo-Matos, R. I., \& Da vila-Ortiz, G. (2001). Physicochemical and Functional Characterization of Baby Lime Bean (Phaseolus lunatus) Starch, 53, 219-226. http://dx.doi.org/10.1002/1521-379X(200105)53:5<219::AID-STAR219>3.0.CO;2-R

De Garmo E.D, Sullivan W.G, \& Canada J.R. (1984). Engineering Economy. MacMillan Publishing Company, New York.

Efendi Raswen. (2011). kombinasi Pemberian Natrium Bisulfit (NaHSO3) dan Pengurungan Santan Dalam Pembuatan Kelapa Parut Kering. J. Sagu, 10(1), 35-41.

Fortuna, James de. (2005). Ditemukan Buah Bakau Sebagai Makanan Pokok. http://www.Tempo interaktif.com.Diakses 2011.

http://www.kemenperin.go.id/artikel /3312/ Peta- Panduan- $\quad$ (Road-Map)Pengembangan-Kompetensi- Inti- Industri- Daerah. Diakses Maret 2012.

Pentury M.H. (2009). Analisis Sumberdaya Hutan Mangrove Dalam Penyediaan Pangan Tradisional Di Teluk Dalam Ambon. Buletin Dinamika, 2, Kopertis Wilayah XII. 34-42.

Purnobasuki, H. (2004). Potensi Mangrove Sebagai Tanaman Obat. http://www.uajy.ac.id/biota/abstrak/2004.

Sadana. D. (2007). Buah Aibon di Biak Timur Mengandung Carbohydrate Tinggi. Situs Resmi Pemda Biak Num for news_.htm.

Tjitro Soejono, Juliana Anggono, \& Dian Perdana. (2000). Studi Perilaku Korosi Tembaga dengan Variasi Konsentrasi Asam Askorbat (Vitamin C) dalam Lingkungan Air yang Mengandung Klorida dan Sulfat. Universitas Kristen Petra. 